\title{
Jubilee Mugs: The Monarchy and the Sex Pistols ${ }^{1}$
}

Alex Law

\begin{abstract}
With rare exceptions sociologists have traditionally had little to say about the British monarchy. In the exceptional cases of the Durkheimian functionalism of Shils and Young (1953), the left humanism of Birnbaum (1955), or the archaic state/backward nation thesis of Nairn (1988), the British nation has been conceived as a homogenous mass. The brief episode of the Sex Pistols Jubilee year song 'God Save the Queen' exposed some of the divisions within the national 'mass', forcing a re-ordering of the balance between detachment and belonging to the Royal idea. I argue that the song acted as a kind of 'breaching experiment'. Its wilful provocation of Royalist sentiment revealed the level of sanction available to the media-industrial complex to enforce compliance to British self-images of loyal and devoted national communicants.
\end{abstract}

\section{Keywords}

'Breaching experiment'; 'detached belonging', 'double declaiming'; Michael Billig; the monarchy; mass society; everyday life; The Sex Pistols.

\footnotetext{
${ }^{1}$ Thanks to Alistair Campbell for discussions about the role of punk. Jim Moir made several useful suggestions about language and the monarchy. Thanks also to the comments made by two referees.
} 
The monarchy, monopoly and masses

A whole number of reasons have been proposed for the waning fortunes of the British royal family. In the 1980s followers of the Gramscian 'hegemonic rule' school (cf. Hall and Jacques, 1983) dubbed 'authoritarian populism' Margaret Thatcher's neoliberal counter-revolution and her regal style, a contradictory mixture of anti-statism and competitive individualism, which began to undermine the prerogatives of traditional authority. For some feminists, the Diana death-cult is evidence of the challenge made to traditional patriarchal authority by a (post-)modern Material Girl. For others like Tom Nairn it is evidence of the slow tectonic shifts that the entire British superstructure needs to take to tackle the outdated 'glamour of backwardness', the constitutional source of UKanian decline.

In each case the picture of Britain is a highly selective one, worked-up through a narrow selection of the 'great ones'- Thatcher, Diana or Elizabeth II. Each provides a focus for unsatisfied desires for equality either of consumer choice (Hall and Jacques), powerful women inside the superstructure (feminism) or national selfdetermination (Nairn). Missing here is any sense that cultural and political symbols and representations tell us hardly anything about the deep cleavages in the material practices of 'British society'. Moreover, this focus on the 'great ones' rests on unspoken assumptions about the 'low ones', the invisible 53 million or so existing beyond the superstructural elites and media celebrities. In other words, some version of the 'mass society' thesis bolsters star-struck sociology. Of course, the old Frankfurt School idea of a homogenous social lump manipulated by the 'culture industry' is far too vulgar for dealing with today's social and cultural complexities, depthless pick n' mix identity construction, knowing narratives of the self, and so on - a narcissistic sociological obsession with the sacralised individual.

British society had changed in numerous ways since the Coronation in 1952. It has been profoundly altered by the restructuring of the world economy, and technological and political change. Mike Savage (2002: 82, emphasis added) summarises such tumultuous change: 'Rapid mobility, new forms of risk and insecurity, the erosion of fixed social and territorial boundaries and the final eclipse of tradition have all been seen as elements of contemporary social change'. But is the 'final eclipse of tradition' 
really at hand or is it a post-modern fantasy? In this radically changed world a traditional focus on social class no longer fits for many contemporary sociologists. Class is seen as far too ambivalent as an 'identity' to any more form, to the extent that it ever did, the organising principle of how everyday life is experienced by individuals (Savage, 2002). Where attention is drawn to multiple social divisions of class, gender, 'race', place, nationality, disability and sexuality it is often to claim that they rarely reinforce each other (Braham and Janes, 2002). Nowadays social 'difference' and 'contested cultural meanings' are increasingly highlighted. The mass society thesis thus loses out to a 'mass of difference' thesis. The baby of 'class' risks being thrown out with the bathwater of 'mass' society.

At the height of the Thatcher years, for example, Hall and Jacques (1989: 2) could argue that Britain had changed utterly - 'not just incrementally but qualitatively' - and was increasingly characterised by 'diversity, differentiation and fragmentation, rather than homogeneity, standardisation and the economies and organisations of scale which characterised modern mass society'. Their earlier assumption about reactionary populism wielding hegemonic influence over a large mass dissolves into a de-centred world of multiple identities. The increasingly near-monopoly conditions that prevail across the culture industry are bracketed-out as too unseemly 'economistic'.

Yet, just as there has been deep and profound change in British society so also has there been continuing trends and patterns from the 1950s. In terms of income and wealth, material inequalities in Britain have worsened and social polarisation has grown apace (cf. Ferguson, Lavalette and Mooney, 2002). Fears about the Americanisation of popular culture raised by Richard Hoggart in the 1950s seem to have been fully realised as US mega-corporations like McDonalds, Disney, Nike and Budweiser vie for domination within global consumer capitalism (Herman and McChesney, 1997). If the term 'cultural capital' means anything under near monopoly conditions then it has little to do with Bourdieu's sense of a set of prestigious classbased dispositions and tastes. This refers to 'capital' in the banal sense meant by orthodox economics of a personalised stock of marketable resources.

Alternatively, cultural capital can be viewed as a branch of circulating capital rather like finance capital or state capital. Cultural capital is cultural because it primarily 
trades in signs rather than physical commodities. CDs are available in the marketplace not simply because they take the form of a silvery coloured disc shape, though this is not unimportant, but because of the culturally meaningful signs that are encoded onto the disc, its packaging and the wider cultural dialogue surrounding its production. But it is also capital, a commodity upon whose sale the music-industrial complex hopes to realise its profits and begin a new round of accumulation. What Simon Frith (1992: 52) argued for the music industry applies to more general processes of cultural production: 'Youth music itself has been routinized, and what matters to the industry in this context is the illusion of change, the illusion necessary for continued sales'.

Today, pop's built-in obsolescence, its slavish devotion to the nearly-new sound and the familiar lyric, helps stabilise tradition and routinise pop's shock value. However, now and then pop rejects the prevailing industry standard and radically posits a different sound and sentiment. My interest here is in one such cultural moment where masses, monarchy, and music collided: the Sex Pistols song 'God Save the Queen'. While the background may be well known I wish to situate this historically by briefly considering the sociology of the monarchy beginning with the Coronation twenty-five years earlier. The brief episode of the Sex Pistols Jubilee year song 'God Save the Queen' exposed some of the divisions within the national 'mass', forcing a re-ordering of the balance between detachment and belonging to the Royal idea. I argue that the song acted as a kind of 'breaching experiment'. Its wilful provocation of Royalist sentiment revealed the level of sanction available to the media-industrial complex to enforce compliance to British self-images of loyal and devoted national communicants.

\section{Sociology and national communion}

Sociologists have traditionally had little to say about the British monarchy and its place in the national imagination. The monarchy forms part of the unspoken backdrop of class relations, culture and politics in Britain. Where it has come into sociological view at all it has usually been as a result of a royal ceremonial like the Coronation or Royal Wedding, or a public spectacle like that around the death of Diana SpencerWindsor. A start was made in the very first volume of Sociological Review when Shils and Young (1953) invoked Durkheim's Elementary Forms of Religious Life to explicate the Coronation of Elizabeth II. At the outset they state, 'The heart has its 
reasons which the mind does not suspect' (1953: 63). In other words the 'ordinary people', as they called them, partook of the Coronation ritual in a wholly unreflexive way. People at street parties in the East End of London displayed a 'complete inability to say why they thought important the occasion they were honouring with such elaborate ritual'.

The mystery of the incomprehensible ritual, 'inchoate, dimly perceived and seldom explicit' (1953: 80), was readily disclosed as an instance of the universal sacredness of the value structure of society. Only through regular moments of "national communion' can the irrational desires and hostilities of 'society' be quelled and put under greater values and moral rules, expressed by the very person of the 'great ones'. In this way 'the preponderance of positive devotion to the moral rules' may be reestablished (1953: 66-7). The Coronation was thus the ceremonial occasion par excellence for "the affirmation of the moral rules by which the society lives. It was an act of national communion' (1953: 67). By giving the 'low ones' some proximity to the 'great ones' the sacredness of moral national consensus is renewed.

By the 1950s, the eminent sociologists explained, the British working class had been tamed by warfare, welfare and regular employment. No longer unruly, violent and hostile towards the symbols of ruling class power working class consciousness had been deeply assimilated 'into the moral consensus of British society ... [as] one of the great collective achievements of modern times' (1953: 76). Any lingering hostility felt by the working class had been effectively extinguished by their devotion to Elizabeth II as a sacred love-object: "when love is directed towards a genuinely love-worthy object [it] reduces the intensity of hatred as well' (1953: 78). 'Contact with this vessel of the sacred values' (1953: 80) provided such an intensive feeling of belonging that class hatred could only recede further. ${ }^{2}$

It is little wonder that in his scathing study of the monarchy, The Enchanted Glass, Tom Nairn (1988: 115-20) called this episode 'the Sociology of Grovelling, Part 1'. In his response to Shils and Young, Norman Birnbaum (1955: 23) balked at any talk

\footnotetext{
${ }^{2}$ Indeed, class hostility seemed to have passed over to national hostility in Scotland. Scottish nationalists resented that use of Elizabeth 'the Second' since she was historically 'the First' in
} 
of the nationally integrative function of the Coronation, concluding that 'it is a considerable disservice to sociology to present our discipline as a useful handmaiden of the current effort to make a conservative ideology once more orthodox and unquestioned'. For Birnbaum the British working class remained largely unassimilated to middle class values in contrast to the embourgeoisment of the US working class. The value hierarchy between 'the great' and 'the low' is inverted by Birnbaum: the bitter struggles of the labour movement dragged the monarchy and the rest of the ruling class into a properly national moral life for the first time. But later Birnbaum returns to the unassimilated nature of the working class. Precisely the absence of shared values gave the Coronation its special salience as a break from routine, a temporary relief from conflict, and the fascination with the Queen had less to do with reverence, worship and devotion than with the "cult of adulation built up around certain film stars' (1955: 19).

This is all grist to the mill of Nairn's thesis that superstructural 'backwardness' reflects the 'backwardness' of society. Thus, despite their crawling, Shils and Young are not entirely mistaken about society being in thrall to archaic institutions like the monarchy. Nairn (1988: 122) scoffs gleefully at the academic politeness of the debate '(where Professors accuse one another of "not entirely escaping ambiguity" and failing to "present events in scientific terms")' and their tacit consensus that the monarchy is really a side-show, alternately 'tinsel revels' or a sacred national altar piece. The anti-modern political authority of the monarchy in its guise as 'constitutional monarch' is, for Nairn, entirely neglected behind the shared phoney dichotomy between 'show and reality'.

Birnbaum's humanist mission of a pure working class, undefiled by the taint of national solidarity, making steady progress towards a more democratic form of life, provokes still more vituperation from Nairn, who dubs Birnbaum's intervention 'the Sociology of Grovelling, Part 2'. After all, the monarchy is 'an archaic institution' and, as such, 'may express something deeply and incorrigibly archaic about the society whose institution it is' (Nairn, 1988: 128). Not many Marxists would escape censure for the kind of crude base-superstructure model deployed by Nairn. However, 
the elusive style of his writing often makes it difficult to cut through the thicket in order to arrive at what precisely Nairn's position on the prospects for the monarchy actually is, given that it still reflects a backward society. In any case, when the first edition of Nairn's The Enchanted Glass appeared in 1988 it was deeply marked by the popularity of the monarchy, a popularity which was soon to be reversed in the 1990s, though it is less clear whether society is any less 'backward' now than then.

\section{The Royal balancing act}

As Michael Billig (1992) notes many studies misleadingly focus on the glamour, grandeur or spectacle of the monarchy. The daily reproduction of the monarchy is obscured by an exclusive concentration on the meaning and significance of state formality. For one thing the tradition of the royal ceremonial is rich in its capacity for re-invention and adaptation (Cannadine, 1983). Even more to the point is that the focus on the extraordinary 'one-off' event is the partner to the focus on the personalities and caprice of the 'great ones'. This works to the detriment of a sociological understanding of the everyday 'ordinariness' of the unequal conditions of social life for most of the population in contrast to the unearned fortunes and inherited privileges of the Windsor family.

Other studies, like the Mass Observation [sic] project, have documented the role of and feelings towards the monarchy in the everyday lives of the 'low ones' (Ziegler, 1977). The popularity of the monarchy tends to be confirmed by social surveys. For instance, less than 9 per cent of respondents to the 1995 British Social Attitudes survey agreed that the monarchy should be abolished while two-thirds thought the monarchy important for Britain and supported the heredity principle of succession (Jowell, et al, 1996: 253). The figures supporting the monarchy in 1999 were almost identical, indicating a high level of consistency (Jowell, et al, 2000: 294). This level of support tends to be lower in London and fell to only half in Scotland, suggesting a much weaker attachment to the symbols of Britishness and/or inherited privilege (Jowell, et al, 1996: 13).

Acceptance of this state of affairs is, for Billig, not as straightforward as 'snapshot' surveys or the mass society perspective suggest. Common sense is arrived at through 'ideological dilemmas', which are argued out by utilising common themes to deal 
with the gaps in what Gramsci (1971) called 'contradictory consciousness'. This allows some dialogical play between social practices and ideology and permits more qualified and dynamic accounts of the cultural mediation of the monarchy, one far removed from the idea of 'the mass' that informs Birnbaum's humanist account of the noble proletariat, Shils and Young's sacred functionalism and Nairn's elevated, metaphysical generalities about national 'spirit-essence' and the like.

The monarchy form part and parcel of the familiar routine and repetition of the everyday. Billig's key argument is that in their everyday speech ordinary British 'subjects' negotiate the Royals as an ideological dilemma through a sense of what I will call 'detached belonging'. This allows them to navigate the various distances between proximity and remoteness to the 'great ones', to be both loyal and treasonous, formal and familiar, respectful and mocking, and so on. The daily struggle of the monarchy thus becomes one of instilling among its subjects a balance between detachment and belonging. Too much reserve, as in the outcry over the Queen's 'discretion' during the media-led mourning over Diana, risks alienating their public. On the other hand, too much familiarity, say over Royal sex lives, risks breeding popular contempt as the mysterious distance recedes to nought.

\section{Into the breach}

The Queen's Silver Jubilee in 1977 provides the occasion for re-considering the relationship between the mass and the figurehead. Unlike 1953 this time the social and cultural 'meaning' of the monarchy was not confined to the pages of an academic journal but was played out in front of society. The release of the Sex Pistols single 'God Save the Queen' in May 1977 acted as kind of 'breaching' experiment across British society. Harold Garfinkel's (1967: 53) original ‘breaching' experiment sought to bring to the surface the 'seen but unnoticed' background features of the everyday based on his assumption that common understanding consists in "compliance with the expectancies of everyday life as a morality'. Disruptions to everyday expectations of what constitutes appropriate conduct potentially sheds greater light on the taken-forgranted than, for example, what people might say in the interview setting.

One risk that Royal rituals such as the Jubilee run is that conventional expectations of popular allegiance and the wholesale silencing of republican sentiment might come 
under direct challenge. The 'seen but unnoticed' might be breached. Political opposition to the Jubilee in 1977 was relatively muted, confined to the Marxist left, such as the Socialist Workers' Party's 'Stuff the Jubilee' campaign. On the surface the Jubilee proved a great success. After a slow start, lack of popular interest had been transformed by the time of Jubilee weekend of 4-5 June, with English streets filled with bunting and Union flags, around 4,000 street parties in London alone and an estimated crowd of one million turning out for the Royal Procession on 7 June. In Scotland popular euphoria was much less evident, despite an extra two days' paid holiday. Many of the special Jubilee mugs given to Glasgow schoolchildren were smashed off playground walls. It was this defiant audience that the Sex Pistols tapped into.

Image, sound and words combine in the Sex Pistols to force a 'taking of sides' throughout society. Subsequently, this has been recovered as simply another stitch being added to 'rich tapestry' of British rock heritage and a straight line drawn to the utopian elements of 1960s hippy 'counter-culture' (Home, 1991; McKay, 1996). It was not understood as such at the time. In general, the group's appearance and demeanour seemed threatening to good taste and good order, belligerently sneering and swearing, dressed in an anti-glamour style of tattered clothing, bent postures and contorted facial expressions. Nothing could have been more removed from the uniform, upright hygiene of Royal dress. The sound added a distorted intensity to pop music, a sharp, jarring noise compared with the polished production jobs in the pop charts and a shock against the complacent 'virtuoso' sounds of 'progressive' rock. While 'God Save the Queen' deployed chord patterns familiar to rock n' roll the song's anger and venom, sounds spat out rather than played or sang, replaced the more overtly sexual energies of traditional pop.

The consternation raised by the image and sound of punk was matched by the song's lyrics. 'God Save the Queen' was chosen as the title, against the original 'No Future', precisely to maximise the level of provocation. By calling direct attention to the official national anthem the Sex Pistols forced their alternative version into public consciousness. The song's words openly flouted pop etiquette by questioning the nature of the society and the role of the Crown. The state is outrageously compared to 'a fascist regime', which has turned the Queen into its servant, 'they've made you a 
moron'. The archaic Imperial hangover is compared to 'a mad parade' which has sent the English nation to sleep, 'England's dreaming', avoiding the realties of its own pitiful subjugation. John Rotten, the singer, sneers, 'We're the future - your future', implying that the whole social edifice will soon face a serious threat, 'a potential $\mathrm{H}$ bomb', to its continued existence.

An overwhelming force of hype and spectacle demanded and expected public conformity during the Jubilee with its heightened moral rules of national communion. The Sex Pistols exposed the underlying levels of coercion held in reserve for any rejection of compliance with the sovereign order of things (Savage, 2001). First, workers at the manufacturing plant pressing the single went on strike over its antimonarchy sentiment and the following day platemakers refused to print the record sleeve, which had Jamie Reid's artwork depicting a safety pin through the mouth of the official Cecil Beaton portrait of the Queen. ${ }^{3}$ Second, the promotional campaign was beset by a series of bans as the media-industrial complex moved to suppress its gross infringement of decency and taste. Adverts were banned from TV and radio and both the IBA and the BBC banned the single itself. Major retailers like Woolworths, Boots and WH Smiths refused to stock the single. Third, when the Sex Pistols still managed to sell 200,000 copies in a fortnight 'God Save the Queen' was kept from the number one position in the national pop charts by a Rod Stewart single, despite 'God Save the Queen' selling twice as many that week. Credible allegations circulated of chart-fixing. Virgin record stores, owned by the same company as the Sex Pistols label, were removed from the weekly census of record sales (Savage, 2001: 364-5). Finally, MPs and the tabloid press led a moral panic to 'destroy' the Sex Pistols, leading to physical assaults on members of group.

\section{Out of the breach}

In the Silver Jubilee week the Sex Pistols acted as a kind of 'breaching' experiment, bringing to the surface the kinds of coercion that routinely, 'seen but unnoticed', underwrote the investment in the monarch with devotional levels of national communion. Yet once doubts were forcibly raised in front of the public any casual sense of tacit consensus about the monarchy was disturbed. In hindsight 1977 was

\footnotetext{
${ }^{3}$ Less offensive than the abandoned one with swastikas covering the Queen's eyes.
} 
perhaps the final point around which such an operation of enforced compliance could be mounted to stabilise the British monarch's position as a sacred object, embodying the desires and fears of a mythical, unified mass by welding it into a glorious national community.

By 2002, the year of the Golden Jubilee, the former Sex Pistols singer and lyric writer, John Lydon, could claim to have always been ambivalent towards the monarchy. 'I was never pro them or anti them. I just think that if we are going to have a monarchy it may as well work properly' (in Hattenstone, 2002: 2). Lydon thus deploys one of the familiar themes noted by Billig in the cynical negotiation of detached belonging, that of 'double-declaiming'. Lydon now claims to stand neither for or against the monarchy, neither wholly opposed nor wholly embraced, but maintains an aloof independence from the ideological dilemma of the monarchy's inherited privilege. Indeed, any hint of opposition completely gives way to fatalistic acceptance - so long as the monarchy exists let's make it work. Contrary to this cynical ambivalence, when Lydon was Rotten his 'God Save the Queen' was understood on all sides as a breach of Royalist etiquette, not a plea to perfect it. It gave cultural expression to and helped shape the fissures between mass and figurehead. Indeed, Dave Laing's (1989: 77) analysis of Rotten's vocal style identified the gratuitous pleasure the singer takes, and which the audience is also invited to take. The accentuated phrasing deployed in comparing the Queen to a 'mo-rrr-on-er' 'connotes a relish on the part of the singer in making the comparison'.

Former Sex Pistols manager, Malcolm McLaren (2002), remains utterly opposed to the Royal Family, 'a story about hypocrisy and at the same time a story about Britain. A celebrity brand with an immense PR machine behind it ... They are a brilliant metaphor for all that is pretentious, deluded, selfish and insincere with the UK'. Whether a 'story', 'a brand' or 'a metaphor', nothing is coming into view remotely capable of the breach committed by 'God Save the Queen' twenty-five years ago. McLaren complains that Jamie Reid's 'Queen' artwork is now sold as a T-shirt in Beverly Hills and is modelled for fashion magazines like Vogue: 'the slogan is now the antithesis of what it originally stood for, and its imaging inadvertently could be said to help promote the brand, the royal family, the "firm" (as the Duke of Edinburgh is so fond of saying - actually a term often used to describe a criminal gang), the 
Queen'. When everyday ideological arguments about the monarchy are conducted in a low key cultural capital recuperates the subversive image, as Adorno anticipated. Individuals may argue over contradictory ideas or ideological dilemmas about the monarchy but a wider culture of compliance will prevail so long as ideological alternatives remain submerged.

\section{Bibliography}

Billig, Michael (1992) Talking of the Royal Family, London; Routledge.

Birnbaum, Norman (1955) 'Monarchs and Sociologists: A reply to Professor Shils and Mr. Young', Sociological Review, 3.1: 5-13.

Braham, Peter and Janes, Linda (eds) (2002) Social Differences and Divisions, Oxford: Blackwell/The Open University.

Cannadine, David (1983) 'The context, performance and meaning of ritual: the British monarchy and the "invention of tradition", in Eric Hobsbawm and Terence Ranger, eds., The Invention of Tradition, Cambridge: Cambridge University Press.

Ferguson, Iain, Lavalette, Michael and Mooney, Gerry (2002) Rethinking Welfare: A Critical Perspective, London: Sage.

Frith, Simon (1992) 'From the Beatles to Bros: Twenty-five years of British pop', in Nicholas Abercrombie and Alan Warde (eds) Social Change in Contemporary Britain, Cambridge: Polity Press.

Garfinkel, Harold (1967) Studies in Ethnomethodology, Englewood Cliffs, NJ: Prentice-Hall.

Gramsci, Antonio (1971) Selections from the Prison Notebooks, London: Lawrence \& Wishart.

Hall, Stuart and Jacques, Martin (eds.) (1983) The Politics of Thatcherism, London: Lawrence \& Wishart.

Hall, Stuart and Jacques, Martin (eds.) (1989) New Times, London: Lawrence \& Wishart.

Hattenstone, Simon, (2002) 'This is my Britain. Not some German tourist's', The Guardian, Friday Review, 17 May, 2-4.

Herman, Edward and McChesney, Robert (1997) The Global Media: the New Missionaries of Global Capitalism, London: Cassell. 
Home, Stewart (1991) The Assault on Culture: Utopian Currents from Letrisme to Class War, Stirling: AK Press.

Jowell, Roger, Curtice, John, Park, Alison, Brook, Lindsay and Thomson, Katrina (1996) British Social Attitudes: The $13^{\text {th }}$ Report, Aldershot: Dartmouth Publishing/Social and Community Planning Research.

Jowell, Roger, Curtice, John, Park, Alison, Thomson, Katrina, Jarvis, Lindsey, Bromley, Catherine and Stratford, Nina (2000) British Social Attitudes: The $17^{\text {th }}$ Report: Focusing on Diversity, London: Sage/National Centre for Social Research.

Laing, Dave (1989) 'The grain of punk: an analysis of the lyrics', in Angela McRobbie (ed) Zoot Suits and Second-Hand Dresses: An Anthology of Fashion and Music, London: Macmillan.

McKay, George (1996) Senseless Acts of Beauty: Cultures of Resistance since the Sixties, London: Verso.

McLaren, Malcolm (2002) 'Monarchy in the UK', Sunday Herald, Seven Days, 19 May: 1-2.

Nairn, Tom (1988) The Enchanted Glass: Britain and its Monarchy, London: Radius. Savage, Mike (2002) Social exclusion and class analysis', in Braham and Janes (eds) Social Differences and Divisions, Oxford: Blackwell/The Open University. Savage, Jon (2001) England's Dreaming: Sex Pistols and Punk Rock, London: Faber \& Faber, second edition.

Shils, Edward and Young, Michael (1953) 'The meaning of the Coronation', Sociological Review, 1.2: 68-81.

Ziegler, Philip (1977) Crown and People, London: Collins. 